\title{
Intermestic Approach: A Methodological Alternative in Studying Policy Change
}

\section{Dyah Estu Kurniawati}

\begin{abstract}
In policy change study, there are at least two main methods used, namely the domestic and international approaches. The classification of approaches is not only based on who the actors are involved in the policy change process or where the source of influence comes from, but more fundamentally each approach emphasizes a different political arena. The domestic approach that is dominant in the study of political science and public policy administration explains policy change as an arena of domestic actors in the fight for their own self-interests. Meanwhile the international approach developed in the study of international relations oversees policy change as an arena for the achievement of the international or transnational actors' interests who want a policy change either by pressuring for changes or providing preferences that can be selected voluntarily by the governments in the decision-making process.

This paper aimed at reviewing the methodology of the two approaches that had existed previously and trying to introduce an alternative approach called intermestic (international domestic). The intermestic approach is useful to analyse the policy change in the globalization era that occurs as if the world is "borderless". This approach starts with the explanation that the domestic and international categories are no longer relevant. In other words, the intermestic approach emphasizes the one fatal mistake that we did was precisely in the selection of the domestic and international arena in the policy change process because the world was headed for a "one space or global political arena". However, in the intermestic approach the idea of state sovereignty is an important aspect and the government still has the main role in the policy change process in addition to those influences of other actors. Nevertheless, the role of states becomes ambiguous because the globalization process has redefined the sovereignty rights and political power of the nation state.
\end{abstract}

Keywords: policy change; intermestic approach; globalization; borderless world.

\section{Globalization and Illusion of Isolation}

Globalization has created a global structure which is as if there exists a borderless world as a result of the international movement caused by industry, investment, individuals, and information which is now known as the $4 \mathrm{i}$ (Ohmae, 1992). In addition, globalization 
also generates ideas and knowledge that can create an international network that shifts easily between state or non-state actors who have the same awareness related with a particular issue, including issues related with, and in the process resulting in, government policy. However, the emergence of this 'borderless' network does not mean terminating the authority of the nation state (state authority). The process of redefining the state authority happens so that the state becomes more open in facing the flow of ideas which is beyond their territorial limits and, as its consequence, involved in conducting the experiment of the new global policy (Rhoeds, 2000; Heritier, 1993; Kickert, Klijn \& Koppenjan, 1997). In the process, the power and the interest of the nation state does not become meaningless but is redefined and relocated so that it is appropriate with the development of globalization.

The fundamental political processes that result from globalization create a situation where the study of contemporary policy cannot ignore the interrelationship between the domestic and international context in the policy making process. Apparently, globalization resulted in both challenges not only towards the national policy of a country because of the 'borderless' idea and the global network policy that can influence the national policy, but also towards the theorization of a particular policy that preferred being isolated either in the domestic or in international spaces. Because of globalization it is difficult to differentiate between the policy which is influenced by international politics and the policy which is influenced by the domestic policy, because both are interrelated. The process of political change is now formed in the context of this interrelationship and as a result a new approach called the intermestic (international-domestic) approach is needed.

This writing is dedicated to explain what is meant by the intermestic approach, how it is different from the other approaches, and why this approach is direly needed in this 'borderless' globalization era. The explanation begins with the mapping of various models of policy change which became the main flow in 
either domestic-based or international-based approaches as the unit of analysis. Then the writer clarifies the position and function of the intermestic approach in the framework of "capillarity" to reveal that the separation of domestic and international arenas in policy study in the globalization era is merely an illusion. In this case, "capillarity" is defined as the process of "leaking" of the influences which are either ideas or knowledge which go beyond the territorial limit of a nation state. This process illustrates the increasingly blurred extension of the limits set between the domestic and international arenas. The policy change therefore happens due to interconnecting among and within governances. The framework of capillarity is adapted from the principles of capillarity in Physics which explain that fluid can "leak" from one domain to another through small capillary pipes as if it relativizes the limit and goes even against the common gravitational laws. With this capillary analogy, it is expected that the methodological explanation about intermestic approach can more easily be understood.

\section{Variations of Explanation about Policy Change: Domestic vs International}

Policy change can be explained by a number of theories which are developed based on different thoughts and methodology. There are many theories that have resulted from exclusive studies in a particular country and have ignored the international or across nations process so they are considered as domestic approaches. There are also studies which have paid little attention to the internal dynamics of a country so that they are categorized as international approaches. The ones that are included in domestic approaches with varied analysis levels in the domestic areas are: the institutionalist model, the pluralist model, the rationalist actors model, and the advocacy coalition models. While the ones that are included in international approaches are: the external pressure (neorealist) model, the global preference (neoliberal institutionalist) model, and the structural/globalist model. Methodological reviews of the 
models from both approaches are done to show the weaknesses of both approaches in the more globalized world and at the same time to emphasize the importance of the intermestic approach.

\section{Domestic Approach: Policy Change as the Interest of Domestic Actors}

The domestic approach covers several explanation models of policy change. The dominant models of this type are: the institutionalism model, the pluralism model, the rationalism model, and the advocacy coalition model. These are called the domestic approaches because the actors' characteristics that are involved and concerned in the process of policy change are the actors in the domestic territory, either state or non-state actors. This approach therefore has never considered the external factors seriously. This writing then will briefly analyse the models one by one.

For the followers of the institutionalism model, policy change is considered as the results from the nation's efforts in obtaining the decided objectives. The governments as the main actors of the policy are considered as the whole power, which has the rationality to actualize the states' interests (Scocpol, 1985). In this model, there is no competition among actors that might influence the policy change. There are no "politics" in the process of policy arrangement because all are directed to the attainment of national interests that are homogenous (Allison, 1971). The approach, which is state-centred illustrates the state institution which sometimes acts stable and sustainable for a long period of time and the policy process is illustrated as a system in the form of steps, consisting of agenda setting, policy formulation, policy implementation, policy evaluation, policy change, and policy termination.

The outline of this approach has the strength in the form of the simplification of social and political reality and the complex interaction between actors in the policy process. However, this part is the main challenge, because basically policy making is related with detailed and complex processes. But concerning the most essential 
aspect, the institutionalism model never pays attention to the role of ideas in the policy change because the focus of the study is more on the factors of national interests. In explaining international partnerships for example, the focus is not on the partnership itself, but on the factors of interests that the nation wants to attain in the international partnerships being made (Keohane, 1984; Oye, 1986).

On the other hand, the pluralism model considers this complexity. According to the pluralism model, the definition of the problem and the determination of policy agenda is basically the result of the competition among different groups. Policy change needs wide coalition supports from various interests groups which can be based on either function, interests, values, perspectives, or identity. Policy change creates the winner and the loser. Therefore, policy change will only be possible if the coalition of the winner groups (candidate) is strong enough to influence the policymakers in implementing a particular policy. For the followers of this model, reducing the policy process becomes the process of rationalization of the state interests by the elite and is the simplification of the excessive and misleading political reality. The policy process is more complex than that. In policy process, the government should sometimes face other entities such as parliament and interest groups so that there are three main actors in the policy making process, namely Bureaucrats, Parliament and Interest Groups. Those three compose what is so called the iron triangle, which takes the role of defining problems and determining the policy that will be made or changed as the solution. In this case, the state is considered as a neutral arena for either competition or consensus of the interests groups in forming policy results. In line with this neutrality, each group has the same access to the policy makers (Dahl, 1994).

Congruent with what can be imagined from the explanation so far, the strength of this model is in its ability to explain policy change as a bigger and more complex change in the society. Policy change is closely related with friction of interests among several pressure groups in the policy making process in the domestic arena. 
However, this model is not much different from the institutionalism model which ignores the importance of ideas. While the first model emphasizes the state interests, the second model diverts the pressure onto group interests.

Next is the rationalism model. This model begins with the wide utility maximalization assumption which is developed in economics. A state is considered as consisting of rational individuals who act to obtain their own needs. For rational choice theory, public policy is the result of political interactions among rational actors to maximize their interests for themselves. The policy is made based on the calculation of profit and loss, and alternative choices that might give the biggest profit, or the least loss, will be selected as the policy. In this case, the rationalism model can be done if the policy makers know what they want and what the society needs, knowing all of the policy alternatives and their consequences, as well as choosing the most efficient policy alternative. In addition, this model has some weaknesses because human rationality is limited (bounded rationality). This bounded rationality means that human beings have limited cognition in the ability to process information and to understand what constitutes their needs. This limitation is then materialized in three forms. First, human beings tend to pay attention to information or stimuli which is appropriate with what they believe and neglect what is not. Second, human beings will only confirm the information or stimuli which is appropriate with what they believe. Third, the implication of the first and the second is that human beings can interpret information ambiguously. This theory usually ends up in a circular form of logic, where the actors know their needs because they are acting as rational beings (Mallarangeng, 2002).

According to the rationalism model, an idea is not that important or not extraordinary (epiphenomenal) to be considered because actors always anticipate the results of their action rationally so that it can give the fruits that they want (Shepsle, 1989). In the extreme version of this model, an idea is merely inbred and attached 
to the rationality of the actors. The competing elites use ideas especially in the form of popularity building as propaganda or to legitimate their interests only. Meanwhile, the idea itself will not play the role to determine the policy change. What is meant by interests in the individual rationality model is the maximalization of wealth, but it also covers larger aspects including values and power. An idea is considered as a 'given' so that the rationalism model focuses on calculation variation based on the maximalization of profit (Nau, 1990; Moravesik, 1992).

The advocacy coalition model is rooted in the thought of Freeman's sub-system theory (1965), the study about agenda setting and Hugh Heclo's (1978) policy change, and Paul A. Sabatier and Jenkins-Smith's (1993) Advocacy Coalition Framework (ACF). In this model policy change happens in a fragmented sub-system through a dynamic policy making process. Heclo introduced two important concepts related with agenda setting process in policy change; they were issue networks and technopols. Issue networks involve an informal network which is developed by individuals from various interest groups, public and private organizations, as well as ordinary citizens called technopols who have skills and concerns on the same issues. They share mutual interests and are concerned to influence the policy change process. In line with that in the 1990s Sabatier and JenkinsSmith described policy change done in policy sub-systems which was not merely consisting of the policymakers but also numbers of actors involved in policy problems and implementation. They were not only the iron triangle (bureaucrats, parliament, and interests groups), but also academic analysts, think thanks, researchers, journalists, and actors at the government levels who later formed advocacy coalitions. Advocacy coalitions can be classified based on the belief system and the resources owned while advocacy coalitions in sub-systems are neither static nor monolithic because there is learning process which is policy oriented among related aspects. Therefore, in this model, belief systems, values and ideas' factors take an important role in the policy change process. According to 
Sabatier, to understand the policy change it is necessary to consider factors that make the elites' opinion shift over a relatively long period and are continuously reassessed. Because the policy process tends to be dynamic, it is important that there are policy brokers, namely the parties that are considered to be able to look for logic and realistic compromise among perspectives supported by these advocacy coalitions. Policy brokers do not mean actors who are not interested in the mediation process among advocacy coalitions. To avoid conflict among the advocacy coalitions competing in the policy process even in crisis situation a coalition can be appointed to negotiate a win for the policy broker using the institutional rules (Bratt, 2013).

The advantage of the ACF model developed by Sabatier compared with the previous models in the domestic approach is that this model illustrates that the policy change process is not merely influenced by the policy-oriented learning done by the advocacy coalitions in the sub-system, but is also influenced by the external conditions of the sub-system. Therefore, although it does not explicitly mention the role of international aspects involved in the domestic policy, methodologically this model has given a new perspective in the study of public policy that has been dominated by public administration and political science which tended to be domestic oriented for so long. ACF is a model that explains that the change is not only seen as the competition of various interests but also being formed by policy-oriented beliefs and policy learning. Therefore, ACF gives the possibility for "the test towards policy change" which is determined by the structure of beliefs from the policy actors and is influenced by the external changes (such as economy, social, and political trends) and causing policy learning among actors through a policy community to happen. It is in this part that ACF has the advantage as having the potential to be developed into an intermestic model by widening the subsystem area of policy, to include not only the domestic concerns, but also the international agenda. The policy process does not only happen in each arena but 
can also be interconnected and involve interplay because of the similarity of idea/belief systems owned by the advocacy coalitions in each domain.

However, ACF model also has some disadvantages. In this case, the main disadvantage is in the limitation of the subsystems which are only in the domestic domain. Therefore by the writer, this model is still placed in the context of the domestic approach.

\section{International Approach: Policy Change as the International/ Transnational Actors' Interests}

Different from the domestic approach, the international approach is instead concerned about the roles and the interests of international and transnational actors in policy change. When being identified, this approach has at least three models of policy change; they are the external pressure model, the global preference model, and the structuralism model. The next part will discuss each model and its critics.

In the external pressure model which is based on Neorealism ideas, policy change in a particular country tends to be considered as a way to create a feeling of peace in the middle of an international policy constellation which is anarchic and uncertain. Therefore, the role of government is not that important because the state behaviour is influenced by international systems. As a result, although states have different characteristics, there is a tendency to have the same behaviour (Nye, Jr., 1988). For example, the intensity of interdependency and the degree of institutionalization or internalization of ideas and international rules in domestic policy is not different among nations although the conditions of each of the actors are different. According to this model, the management of the international world mostly represents the interests of big developed countries (Mearsheimer, 1994/1995). The larger and more dominant countries - even hegemonic_play an important role in preventing violations of the established rules by means of the implementation of fines and penalties in the form of particular 
behaviours and actions towards the violators (Gilpin, 2001). As a result, the motivation of policy adaptation in a particular country tends to be a way to seek security in the middle of an international political constellation which is anarchic. Therefore, the role of the actors is not as important because the actors' behaviour is influenced by the structure.

In this context, a policy change in a country which is like the policy in other countries, is the adaptation of the national agenda to the global demands so that the related country is "safe" and does not get a penalty or fines from big countries which are behind the international donor agencies, such as IMF, World Bank, UNDP, ADB, GTZ, USAID, etc (Sahdan, 2005). This consideration explains that the international system can homogenize the behaviour of different states. Because of this process, this model can understand the rationality and actions of a country which can always be placed in the framework of efforts to better adapt with its surrounding.

Nevertheless, this systemic approach cannot accommodate the varied domestic demand factors believed by many parties which are influential in the process of policy change because in this approach, the role of the actors is considered unimportant, and not more than a response towards system determination. In addition, this approach cannot be used to analyse the interests behind the international agency programs mentioned previously. In other words, the neo-realism approach can only partially explain the process of policy change in a country.

The global preference model is based on the liberalist idea that the process of policy making involves actors outside the country such as individuals, interest groups, multinational companies, NGOs/INGOs, and international donor agencies, such as the IMF, World Bank and UNDP. The governments do not always act as the main actors because there are many non-state actors that take a role, including non-transnational state actors, so that the policy process of a country is difficult to be seen separately or even cannot be considered independent. The issues being discussed are not merely 
limited to the needs of the safety and politics of the country, but cover wider aspects such as economic, humanitarian, environmental issues, etc. International agencies determine the agenda, encourage the coalition formation, and provide the guidelines for countries in solving the problems they are facing. Even in particular issues it is valid to apply the international regime which closely controls the behaviour of its members and applies penalties if violations happen. Therefore, the interdependence phenomena and institutional reference or international actors become the main instrument of policy change (Keohane, 1988).

The advantage of this approach is in its argument that countries in policy decision making can choose a system or a form of policy which is considered to be the most appropriate for themselves, by the implementation of the rational choice which is considered as the most important aspect of this model. The leaders of the countries can determine the appropriate balance from various policy choices, and determine the appropriate strategy in making a good and rational policy. The process of policy making which is as far as possible "immune" from the political process because the involvement of the political agendas can be the disruption from the technocratic consideration which has the ability to make scientific calculation when choosing the policy.

However, the explanation about the process of policy change which is "neutral" has disadvantages. In reality, the policy making in government is not merely choosing "rationally" the "appropriate" decisions in a technocratic and free of value way, but fundamentally is more formed by the contention of ideas and the competition of interests (Hadiz, 2004). Therefore, the explanation of the global preference model denies that rationality can be subjective and cannot be separated from conflict of interest. However, as mentioned previously, the emphasis on the conflict of interest itself is problematic because such emphasis tends to ignore the important meaning of an idea in the process of policy making.

The structuralism model explains that policy or policy change 
happening in a country is not determined by the government because a country is only an instrument of the dominant class. This policy cannot be forced by the outside power, for example by the donors as a requirement to get foreign aid. This model is much influenced by the class analysis tradition developed by Karl Marx, which explains the relationship between the capitalist class and the working class in a community or nation (Viotti \& Kauppi, 1997). The policy process is interpreted that the competition among classes and states is only the instrument for the dominant class, that is the capitalist class. The structural model adapts this way of thinking and studies the relationship between the developed and developing countries as forms of an exploitative relationship (Budiman, 1996). In defending the interest of its economic domination, the developed countries which represent the interest of the capitalist class sometimes use the development agencies and international monetary funds to oppress the developing countries so that they facilitate the global capital operations in their own countries. Therefore, the policy process especially in developing countries is influenced by the interest of external actors, in this case the developed countries and the interest of capital owners behind them, which impose policy onto the developing countries' government as the requisite support and return for their investment.

The advantage of the structuralism model is in its critical analysis towards global capitalism hegemony which is previously considered a "given". Nevertheless, the practice of national relationship is not always pessimistic as it is imagined by the structuralist in which policy change is considered as enforcement from the greater power and always harmful. In reality, there is always a "room to manoeuvre" for the domestic decision makers to learn in the process of policy change. The states' role, and therefore domestic factors that shape the role of the state, cannot be neglected and can be the important base without seeing the international world pessimistically. Besides, the structuralist approach also puts great pressure toward the material needs, that is about global 
capitalism interests in accumulating profit continuously. As a result, this approach fails to grasp the important role of ideas in forming the policy and behaviour of the states.

\section{Intermestic Approach: Policy Change as Idea, Networking, and Learning Construction}

When the interconnectedness between the domestic and international arenas became more inevitable because of globalization process, policy study in the late 1980s experienced vocabulary changes which dominated the explanation and controversy. The emergence of terms governance, institutional capacity, networks, complexity, trust, deliberation, transnational, and interdependence, shifted the previous dominant terms such as state, government, power, authority, loyalty, sovereignty, participation, hierarchy, and interest groups (Hajer \& Wagenar, 2003). Policy change presently is not merely considered as a conflictual process resulting from the struggle for interests and power because now the role of transnational ideas is considered (Adler, 1986, 1992; Smith, 1988; Hall, 1989, 1993, 1997; Onuf, 1989; Sikkink, 1991; Weber, 1992; Goldstein, 1993; Goldstein \& Keohane, 1993; Risse-Kappen, 1994; Katzenstein, 1996; Wendt, 1997; McNamara, 1998; Mandelson, 1998; and Berman, 1999).

Either vocabulary changes or attention focus in policy study illustrates the new change in political practice as well as the change of the theme of the policy study. Nevertheless, the tendency of policy theorization is still dominated by domestic and international approaches. Whereas with the power structure change in the globalization era, the state policy change process is difficult to be done if it is only understood as domestic political activity without considering the factors of transnationalization of ideas from the actors outside of the territory because there are many similarities in timing and policy characteristics in many countries. For example, the wave of the third democratization from the 1970s until the 1990s (Huntington, 1991) cannot be explained without connecting it with the diffusion of democratic ideas which goes beyond state limits. 
This development, as is well known, results in important changes related with the policy in terms of making the government closer with the international community, providing wider chances for the participation of the community in the political process, and helping the development of responsive policies and services. During the decade of the 1990s there was also the decentralization wave with the main mission for the development and good governance practices (Conyers, 1983). During that period, many countries from various parts of the world with different backgrounds of history, political systems, and a wide variety of levels of development made changes in decentralization policy using very similar concepts and strategies (Strechl, 1999). The emphasis was on political rights, civil liberty, institutional pluralism, and pluralism in policy choices. These phenomena justify the importance of the intermestic approach that can illustrate the relationship between the international and domestic arenas in the process of policy change because of the traffic of transboundary ideas.

As an illustration, there are some explanations about why the democratization wave and decentralization shift with changes in market ideology in various countries happened from the late 1970s and the beginning of the 1980s. If using the international approach, these phenomena are the reflection of the domination of orthodox neoclassical theory which globalized and then were implemented together in either developed or developing countries as the preference which was recommended by international donor agencies. A large number of academic excerpts explaining about the excellence of market economy from the followers of neoclassical economics can be compared with the dirigisme dogma from Keynesian macroeconomics stated in the New Right (Kanan Baru) intellectual publications such as Lal (1985), Hicks (1989), and various publication of the World Bank since 1981 (1981, 1993).

However, the domestic approach will never believe that the ideas of Kanan Baru are the most important factors behind the deregulation of policy change, liberalization, and privatization in 
developing countries following democratization in the late 1970s and 1980s. The source of adoption of market ideology in developing countries is seen as more domestic than external. According to this approach, it is difficult to imagine that market ideology directly influences the policymakers in developing countries and it is less possible for the policy decision makers to read the writings of the intellectuals of Kanan Baru which elaborate the strengths of market economy compared with the government intervention. If only they had read them, it is still not clear how far those ideas can be accepted and influence the policy decision makers in making policy decisions.

The intermestic approach fills the gap left by the domestic and international approaches in its explanation about the influence of Kanan Baru ideas in developing countries. From the perspective of the intermestic approach to policy change, the simultaneous adoption of market ideology at the end of the 1970s and the beginning of the 1980s reflected the "infiltration" of Liberal ideas which happened in knowledge networks/KNETs so that it was able to construct the global policy change. The process of "knowledge transnationalization" (Helleiner, 1990) worked through various media, such as giving scholarships to postgraduate students from developing countries to study at universities in which Kanan Baru ideas were dominant such in the USA and Europe in the 1970s. The alumni of those universities in the end became the epistemic community who brought market ideology to the policy cycle in their own countries and demanded economic reformation based on neo-classical economic recipes. Similar processes also happened in training programs offered by international monetary agencies, such as the World Bank for either the technocrats of developing countries or for activists who also were involved in the policy change process. This process was supported by the availability of various international publications which were easily obtained by all parties in all countries such as The Wall Street Journal, The Economist and The Financial Times. It is in these writings that the capillarity 
analogy which strengthens the way of thinking of intermestic thought can be described. The work of the capillarity principle which permeates from top to bottom, from right to left, and to all directions interconnectedly can be used to describe the blurring of the domestic - international limits so that policy change happens with mutual crochet hooks in, among and between governances. Through the network of advocacy coalitions consisting of scientists, technocrats, and possibly some groups such as economic actors, politicians, and the followers of neo-classical economic recipes, journalists either the ones in or outside of the countries interpret and gather again the market ideology arguments so that it becomes appropriate with the domestic context in a continuous learning process, which at the end becomes the basis for the policy change.

Therefore, the study of policy change in the intermestic approach in addition to considering the role of idea construction important, also supports the existence of relational aspects (networking) across nations and policy change itself as the form of learning, and not a forcing by hegemonic actors. Basically, networking is developed because of interdependent actors, who have similar perspectives/beliefs and need resources from other parties to obtain their objectives. Networking can happen across nations either formally or non-formally (Adam \& Kriesi, 2007). The distribution of power in networking can be either concentrated or fragmented; it can be concentrated in the government (state-centred) or it can be fragmented to the nation or non-nation actors although it continues to include the role of the government (state-society centred).

When simplified, the intermestic approach relies on three main arguments. First, the importance of the role of an idea; second, the importance of the networking aspects that are across nations; and third, policy change as the learning process. An idea takes an important role in the policy process because it can help actors (in the public arena) to know their necessary purpose, why this purpose is more important than others, how the purpose will be achieved, and who will be the friend and enemy in the process to achieve it 
(Adler, 1986). Generally, the policy actors in the public arena face many choices and have a variety of impacts or multiple equilibria, or various balances (Goldstein \& Keohane, 1993). The relationship between the actors and policy choices constantly is covered with uncertainty. In such a condition, it is difficult for the policy actors to understand their interests, or if they do, it is not easy to know what policy they need to take to achieve their interests. It is in here that the role of an idea becomes important because an idea can construct an interest and an idea creates a mechanism (an instrument) to obtain that interest. It means, an idea can become a normative foundation and justification for certain decisions and an idea can let the policy actors know about the means-objectives relationship. Therefore, the interest and structure created through policy change is in fact the reflection of an idea. This idea can create a "reality" and bring about the interest that does not exist previously. An idea has the power to change the perception of a group related with their interests, so that it enables policy change to happen. Because of the nature of an idea that can go transnational, the study about an idea becomes important for the intermestic approach which cannot separate between the domestic and international arenas. The "permeation" of ideas which are transboundaries in this approach is analogized as the capillarity process which involves ideas or knowledge networking through the role of the epistemic community as capillary pipes.

The networking aspect itself showed the new architect model in policy study in the 1990s. When referring to the model of policy making in the domestic context which covers agenda setting, policy formulation, policy implementation, and policy evaluation, therefore a significant change in the process of policy making was happening in the contemporary era. In the face of the agenda setting, in this era there is no stipulation who will be responsible, who will have the authority and whose hope will be able to be materialized through the policy. All happens in a political process which is competitive (March \& Olsen, 1995). The policy formulation process is coloured with the policy learning process (Sabatier \& Jenkins, 1993) which 
involves the epistemic community as the "message senders". Policy implementation requires coordination among nations and various institutions because of the similarity of the concerns or issues, and the policy evaluation process involves various parties including either international monetary agencies or professional organizations. There are two types of learning, namely lesson-drawing and social learning. Lesson drawing is the learning process based on their own group's experiences (Sabatier, 1987, 1988, 1993) or based on other groups' experiences (Rosse, 1988, 1991). Meanwhile social learning (Hall, 1989, 1993) aims at only the idea and knowledge induction process which changes the distribution of political resources, butreferring to Kuhn (1962) - the policy change at the end can result in a paradigm change.

The intermestic approach includes the policy change model that gives an important role to idea factors and policy networking which is transnational. An idea in this context is understood as a cognition which can be in the form of a belief system, knowledge or discourse. While networking can be in the form of a policy community, professional network, intergovernmental network, producer network, and issue network (Hudson \& Lowe, 2004). It means, the quest does not necessarily begin from zero because in fact there have been several models which are relatively sensitive towards this matter. Some models have been available for this approach, for example, the network model, the deliberative model, and the constructivist model. These models will be discussed shortly.

The first model in the intermestic approach is the networks model which treats public policy as a pro forma, if not as a series of networking. This model emphasizes relational and informational aspects in policy change because its study is based on the principle that: networking is developed transnationally because the actors are interdependent. This interdependency cannot be avoided because for the realization of an idea of policy, resources from other parties are needed. Networking at least involves two actor groups, namely the country and the transnational actors so it is called interstate-society 
centred. A state still has an important position because it has the resources in the policy process while non-nation actors also have the role in supporting or not supporting the policy change so they form differentiated policy (Rhodes, 1997).

The advantage of the networks model is that it can illustrate the complexity of relations that exists in international relationships in the globalization era. The process of policy change is influenced by the contact patterns and good relations either formally or nonformally in policy networking which is transnational. The typology to deal with network complexity can be based on distribution of power and the type of interaction in the network (Adam \& Kriesi, 2007). The power distribution can be concentrated or fragmented and the interaction type in networking can be in the form of conflict, bargain, or partnership. Policy can be changed and greatly influenced by the pattern of the relationship of those two aspects, that become the adhesive bases of this model as shared resources and shared interests among the "members" of the networking. The epistemic community as the intellectual networking is one of the examples of the network model, in which the role of ideas/knowledge from the actors in their expertise then creates networking transnationally and the influence of the process of policy formulation is highlighted. There are several terms used to identify this intellectual networking, for example epistemic community (Haas, 1999), transnational advocacy networks TANs (Keck-Sikkink, 1998), policy community (Walker, 1981; Brooks, 1994), individual policy entrepreneurs (Mintrom, 1997), intellectual organic (Gramsci, 2013), etc. In the frame of the intellectual network model, policy process is coloured with complexity and uncertainty, and the policymakers do not sometimes know for sure what is in the best interest of the country and how to achieve it. Therefore, the one which represents the state needs advice from intellectuals who have high integrity and expertise and have the technical capacity and mastery of the detailed information about an issue or a policy idea.

The epistemic community according to Haas (1992) is a group of actors (individuals or organizations) who have the same ideas 
and perspectives related with a particular policy issue. They are not limited by narrow organizations which are defined as political institutions (such as executive, legislative, political parties, etc.) but also include communities that so far "dodge" to be defined as political actors, such as universities, research centres, scientific associations, expert staff, etc (Santoso, 2002). Even international institutions which are concerned about the same policy issues can become epistemic communities because the diffusion process of ideas and knowledge knows no national boundaries. Therefore, the members of the epistemic community are plural and transnational. The relationship character of the epistemic community refers to "trust" and "shared appreciation" and if a conflict happens, it will be framed in a consensus decision making process (Jordan \& Maloney, 1997).

Different from Haas, Gramsci who is a follower of Marxism interprets the intellectual network as an intellectual organic whose characters have the relationship with the class interests that they represent. According to Gramsci, an idea takes a role but is always associated with the interests of particular groups, especially the capitalists. Hegemony towards particular groups is not enforced, but is achieved through intellectual organics with cultural or intellectual and political efforts. This means that the class which has power should "universalize" their ideas and interests, and also ensure that ideas and interests are not merely possible but also become the perspectives and interests of sub-ordinate groups so that it results in history blocking and creating hegemony. Generally, the epistemic community has the ability to influence ideas and strategy of policymakers (veto players) in a country through an education process, training, socialization, etc., so that it has the influence in the process of policy change. However, they sometimes do not have veto power directly or formally in the policy process so that they still need good, strong affiliations either personally or institutionally with the policy decision makers in order for their missions to be obtained. 
The second is the deliberative model which explains that policy change happens because of discourse change which manages the pattern of social relations which is normal so that the key of policy change is the discourse interpretation structure. Understanding the behaviour can be done by learning discourse interpretation which is done by the actors who are involved. The policy recommendations can be different because the points of their discourse are different. In this case discourse is interpreted as a thinking system (see, for example, Foucault, 1990). It means that the policy process involves policy discourse to arrange the argumentations that form the policy frame in which there are problematics and their solutions.

The best standpoint to understand the deliberative model is that the language used to discuss policy and its problematics is not neutral. Therefore, to understand how a problem is considered a "problem" one should understand the discourse process, that is what happens when the problem was made and defined in a particular language or discourse. The policy change process is embodied in the struggle to determine the discourse in which the policy problem is arranged by epistemic notions or discourse coalitions which are transnational. This process is called with various names, among others, the discursive process (Santoso, 2010), rational communicative (Dryzek, 1990), deliberative process (Hajer \& Wagenaar, 2003), or social process (Majone, 1989). In this process, epistemic notions or discourse coalitions which work to influence policy will make efforts to arrange persuasive arguments so that they can dominate the policy discourse, which also means determining the direction of the policy. In the deliberative model the most important aspect is discourse because the policy ideas depend on the discourse and counter discourse in the communicative rationality process or discursive process.

The third model that can be a consideration in formulating the intermestic approach is the constructivist model. In this model policy change is a learning process based on the appropriateness of logic and international norms as the important bases of policy change (Checkel, 1997). International norms will be more easily 
internalized and legitimized in domestic policy if they touch the values, identity, or beliefs of domestic actors. However, if outside norms are contradictory, it will possibly be difficult to follow although the possibility continues to exist. Not like the rationalist or structuralist/materialist models which see policy change as a result of rational interest factors, the constructivist model views policy change more from norms or idea factors. The internalization process of international norms is through a cognitive process, in which policy change is not merely forced by the interests but is also influenced by the perceptions, capacity to gain information and learning that can change the interests of the actors involved.

From the explanation above, several aspects concerning policy change from the domestic, international, and intermestic approaches can be summarized in the following table.

Table of Typology of Approaches in Policy Change

\begin{tabular}{|l|l|l|l|}
\hline \multicolumn{1}{|c|}{ Variables } & Actors & $\begin{array}{l}\text { Policy Change } \\
\text { Process (How) }\end{array}$ & $\begin{array}{l}\text { Factors that } \\
\text { influence/ } \\
\text { Important (Why) }\end{array}$ \\
\hline \multicolumn{3}{|c|}{ Domestic Approach } \\
\hline $\begin{array}{l}\text { State centred: } \\
\text { Institutionalists }\end{array}$ & Government & $\begin{array}{l}\text { A-political: decision } \\
\text { making }\end{array}$ & $\begin{array}{l}\text { State interest } \\
\text { defined by power } \\
\text { elites }\end{array}$ \\
\hline $\begin{array}{l}\text { Society centred: } \\
\text { Pluralism }\end{array}$ & $\begin{array}{l}\text { Groups, Iron } \\
\text { Triangle }\end{array}$ & $\begin{array}{l}\text { Political process: } \\
\text { policy making }\end{array}$ & Group interests \\
\hline $\begin{array}{l}\text { Individual } \\
\text { centred: } \\
\text { Rational choice }\end{array}$ & $\begin{array}{l}\text { Individual } \\
\text { Actors; }\end{array}$ & $\begin{array}{l}\text { Political } \\
\text { process: results } \\
\text { maximalization }\end{array}$ & Individual interests \\
\hline $\begin{array}{l}\text { State-society } \\
\text { centred: } \\
\text { Advocacy } \\
\text { Coalitions }\end{array}$ & $\begin{array}{l}\text { Domestic } \\
\text { Sub-system }\end{array}$ & $\begin{array}{l}\text { Learning Process } \\
\text { International Approach }\end{array}$ & Idea/Belief System \\
\hline $\begin{array}{l}\text { Suate Centred: } \\
\text { Neorealism }\end{array}$ & $\begin{array}{l}\text { International } \\
\text { system }\end{array}$ & $\begin{array}{l}\text { Politic Process: } \\
\text { Conflict }\end{array}$ & $\begin{array}{l}\text { The state interests } \\
\text { are extensive }\end{array}$ \\
\hline
\end{tabular}




\begin{tabular}{|l|l|l|l|}
\hline $\begin{array}{l}\text { Society Centred: } \\
\text { Liberalism }\end{array}$ & $\begin{array}{l}\text { Supra-state } \\
\text { Actor/ } \\
\text { Transnational } \\
\text { actor }\end{array}$ & $\begin{array}{l}\text { Politic Process: } \\
\text { Partnership/ } \\
\text { Consensus }\end{array}$ & Global interests \\
\hline $\begin{array}{l}\text { Class Centred: } \\
\text { Structuralism / } \\
\text { Globalism }\end{array}$ & Global Class & $\begin{array}{l}\text { Politic Process: } \\
\text { Conflict/Exploitative }\end{array}$ & $\begin{array}{l}\text { External actor } \\
\text { interests based on } \\
\text { class/hegemony }\end{array}$ \\
\hline Network & $\begin{array}{l}\text { Epistemic } \\
\text { community }\end{array}$ & Knowledge Process & $\begin{array}{l}\text { Shared knowledge, } \\
\text { shared issue, etc. }\end{array}$ \\
\hline Deliberative & $\begin{array}{l}\text { discourse } \\
\text { coalitions } \\
\text { and epistemic } \\
\text { notions }\end{array}$ & $\begin{array}{l}\text { Discursive/social/ } \\
\text { deliberative/rational } \\
\text { communicative Process }\end{array}$ & Global Discourse \\
\hline Constructivist & $\begin{array}{l}\text { Domestic } \\
\text { idea and } \\
\text { international } \\
\text { norms }\end{array}$ & Learning Process & $\begin{array}{l}\text { Norms/Ideas/ } \\
\text { Values }\end{array}$ \\
\hline
\end{tabular}

Processed by the Writer

The intermestic approach maintains the domestic approach logic that government roles remain in the important position in policy change because they have veto power. However, this approach also applies the international approach logic that gives room for the involvement of non-state actors in the domestic and international arenas in influencing the policy change process so that it forms differentiated policy (Rhodes, 1997). The strength of the intermestic approach can be better illustrated and more completely with the complexity of domestic-international interrelationship in the globalization era which is considered borderless. However, the main problem of the intermestic approach that concerns with the role of ideas, networks and learning in the process of policy change is on how to map the ideas and beliefs from the actors (actors' belief) who are involved in the policy change process which is complex on the same canvas so that the complexity becomes the strength and at the same time can reveal any of the weaknesses in the process of policy making. 


\section{Conclusions}

At the beginning, the study of policy change was dominated by the domestic approach which sees the policy change identical with the government administrative process. Non-state actors such as parliaments, interest groups, NGOs, or academicians are also considered in the form of their analyses, but only limited in domestic political aspects. In its development policy change involved international and transnational actors such as donor institutions, INGOs, or intellectual community networks in policy change. This tendency encouraged the emergence of an international approach that was very much influenced by international relationship sciences. But, with the globalization process which now occurs as if there is a blurring of the borders of all nations, analyses of policy change could not separate the domestic and international approaches anymore, in which the role of government remained important but not closing the door to the possibility of the involvement of either international or transnational actors and in the process policy change becomes more learning oriented.

The intermestic approach became important because the globalization of the international system in fact is not only a consequence of domestic politics (dependent variables) like the ones generally studied in the analysis of foreign policy (Waltz, 1959). The new international system could also be the cause (independent variable) of domestic political dynamics (Gourevitch, 1978). Therefore, international relationships and domestic politics are in fact interconnected so that policy change should be analysed interrelatedly using the intermestic approach. 


\section{References}

Addler, E. (1997). Constructivism in World Politics. European Journal of International Relation, 3 (3). 319-363.

Allison, G.T. (1971). Essence of Decision. Boston: Little Brown.

Almond, G.A., \& Powell Jr, G.B. (1978). Comparative Politics: System, Process, and Policy. Boston: Little Brown.

Budiman, A. (1996). Teori Pembangunan Dunia Ketiga. Jakarta: Gramedia Pustaka Utama.

Bratt, D. (2013). Clarifying The Policy Broker in The Coalition Advocacy Framework. Paper presented at International Conference on Public Policy, in France.

Castells, M. (1996). The Rise of Network Society. Oxford: Blackwell.

Checkel, J.T. (1997). International Norms and Domestic Politics Bridging the Rationalist-Constructivist Divide. European Journal of International Relations. 473-495.

Conyers, D. (1983). Decentralization: The Latest Fashion in Development Administration?. Public Administration and Development, Vol 3 (2). 97-109

Dryzek, J.S. (1990). Discursive Democracy: Politics, Policy, and Political Science. Cambridge: Cambridge University Press.

Easton, D. (1965). A Framework for Political Analysis. New York: Prentice Hall.

Finnemore, M., \& Sikkink, K. (1998). International Norms Dynamics and Political Change. International Organization, 52(4), 887-917.

Fischer, F \& Forester, J. (eds.). (1993). The Argumentative Turn in Policy Analysis and Planning. Durham. NC: Duke University Press.

Goldstein, J., \& Keohane, R. (eds.). (1995). Ideas and Foreign Policy: Beliefs, Institutions, and Political Change. Ithaca: Cornell University Press.

Gourevitch, P. (1978). The Second Image Reverse: The International Source of Domestic Politics. International Organizations, 32 (4), 881-912.

Gramsci, A. (2013). Prison Notebooks: Catatan-catatan dari Penjara. Yogyakarta: Pustaka Pelajar.

Haas, P.M. (Ed.). (1992). Knowledge, Power, and International Policy Coordination. Columbia SC: University of South Carolina Press.

Hajer, M., \& Wagenaar, H. (2003). Deliberative Policy Analysis: Understanding Governance in The Network Society. Cambridge: Cambridge University Press.

Heclo, H. (1978). Issue Networks and The Executive Establishment. In Anthony King(Ed.). The New American Political System. Washington DC: American Enterprise Institute. 444-456 
Huntington, S. (1991). The Third Wave: Democratization in The Late Twentieth Century. US: University of Oklahoma Press.

Kana, N.L et al. (eds). (2001). Dinamika Politik Lokal di Indonesia: Perubahan, Tantangan, dan Harapan. Salatiga: Pustaka Percik.

Keck, M.E., \& Sikkink, K. (1997). Activists Beyond Borders: Advocacy Networks in International Politics. Ithaca and London: Cornell University Press.

Keohane, R., \& Nye, J. (eds.). (1971). Transnationalism and World Politics. Cambridge Mass: Harvard University Press.

Keohane, R., \& Nye, J. (1989). Power and Interdependence: World Politics in Transition. Boston: Little-Brown. (2nd ed.).

Keohane, R. (1988). International Institutions: Two Approaches. International Studies Quarterly, 32 (4), 379-396.

Malarangeng, R. (2002). Mendobrak Sentralisme Orde Baru Tahun 1986-1992. Jakarta. Kepustakaan Populer Gramedia.

Majone, G. (1989). Evidence, Argument and Persuasion in the Policy Process. New Haven, CT: Yale University Press.

March, J.G., \& Olsen, J.P. (1995). Democratic Governance. New York: Free Press.

Moravcsik, A. (1993). Preferences and Power in the European Community: A Liberal Intergovernmentalist Approach. Journal of Common Market Studies 31(4), 473-524.

Mas'oed, M. (2002). Tantangan Internasional dan Keterbatasan Nasional: Analisis Ekonomi Politik tentang Globalisasi Neoliberal. A speech on inaugural on professorship at Political Science Faculty of Gadjah Mada University. Yogyakarta: unpublished.

Mas'oed, M. (1994). Negara, Kapital, dan Demokrasi. Yogyakarta: Pustaka Pelajar.

Novak, M. (1999). On Cultivating Liberty - Reflections on Moral Ecology. New York: Rowman \& Littlefield.

Rhodes, R.A.W. (1996). The New Governance: Governing without Government. Political Studies 44.

Rhodes, R.A.W. (1997). Understanding Governance: Policy Network, Governance, Reflexity and Accountability. Milton Keynes: Open University Press.

Risse-Kappen, T., Ropp, S.C, \& Sikkink, K. (1999). The Power of Human Rights: International Norms and Domestic Change. Cambridge: Cambridge University Press.

Rossenau, J.N, (ed.). (1995). Governance Without Government: Order and Change in World Politics. Cambridge: Cambridge University Press.

Sabatier, P.A., \& Jenkins-Smith, H.C. (1993). Policy Change and Learning: 
An Advocacy Coalition Approach. Boulder: Westview Press.

Sabatier, P.A., \& Jenkins-Smith, H.C. (2007). Theories of Policy Process. Colorado: Westview Press.

Santoso, P. (2011). Ilmu Sosial Transformatif. A speech on Inaugural Professorship at Social and Political Sciences Faculty of Gadjah Mada University. Yogyakarta: unpublished.

Santoso, P. (2002). Epistemik Politik dan Pelembagaan Local Good Governance retrieved from http://www.scribd.com/doc/13236005/epistemikpolitik

Scocpol, T, Evans, P., \& Rueschemeyer, D. (Eds.) (1985). Bringing the State Back In. Cambridge: Cambridge University Press.

Shepsle, K. (1989). Studying Institutions: Some Lessons from The Rational Choice Approach. Journal of Theoretical Politics, 1(2), 131-147.

Silke, A, \& Kriesi, H. (2007). The Network Approach. In Sabatier, P. A (Ed.), Theories of Policy Process (pp.129-154). Colorado: Westview Press.

Sugiono, M. (1999). Kritik Antonio Gramsci terhadap Pembangunan Dunia Ketiga. Yogyakarta: Pustaka Pelajar.

Viotti, P.R., \& Kauppi, M. (eds.). (1987). International Relations Theory. Macmillan Publishing Company, New York).

Viotti, P.R., \& Kauppi, M. (eds.). (1999). International Relations Theory: Realism, Pluralism, Globalism and Beyond. Boston: Allyn and Bacon

Waltz, K. (1959). Theory of International Relations. In Greenstein, F., \& Polsby, N. (eds.). 1975. Handbook of Political Science: International Relations, 8. Menlo Park: Addison-Wesley.

Wendt, A. (1992). Anarchy is What States Make of It. International Organization, 46 (2).

Widjajanto, A et al. (2007). Transnasionalisasi Masyarakat Sipil. Yogyakarta: LKiS. 